Notes on Rotuman Grammar.

Author(s): A. M. Hocart

Source: The Journal of the Royal Anthropological Institute of Great Britain and Ireland, Vol. 49

(Jul. - Dec., 1919), pp. 252-264

Published by: Royal Anthropological Institute of Great Britain and Ireland

Stable URL: http://www.jstor.org/stable/2843442

Accessed: 08-01-2016 21:50 UTC

Your use of the JSTOR archive indicates your acceptance of the Terms \& Conditions of Use, available at http://www.jstor.org/page/ info/about/policies/terms.jsp

JSTOR is a not-for-profit service that helps scholars, researchers, and students discover, use, and build upon a wide range of content in a trusted digital archive. We use information technology and tools to increase productivity and facilitate new forms of scholarship. For more information about JSTOR, please contact support@jstor.org. 


\title{
NOTES ON ROTUMAN GRAMMAR. ${ }^{1}$
}

\author{
By A. M. HOCART.
}

THE Rotuman language cannot be elucidated in all its details without a careful examination of collected texts. As such a work must be deferred for some years, I have, while the language is still fresh in my mind, set down the essentials in the hope that they may prove of use to residents in Rotuma and to students of language at home, who might form an erroneous idea of Rotuman if they were to judge it by the existing literature.

For this language has nevier yet, to my knowledge, been fathomed. If anyone should find this hard to believe of an island that has had missions for more than fifty years, I can point to the two totally different orthographies in use in Rotuma, the Methodist and the Roman Catholic, to say nothing of the spelling of the chart and that of visitors. Thus the Methodists spell tafi, the Roman Catholics tèf, Mr. Allardyce, in a paper on "Rotooma and the Rotoomans,"2 tef; to my mind the right spelling should be sometimes tafi, sometimes täf, according as may be required by certain very definite rules. The Roman Catholic version of the Lord's Prayer runs: "Otom Ufa e selo la ha ou as, la leum ou puer ..." The Methodist version is very different, but translating the Roman Catholic into their spelling, we should have: "Otomis oifa e seto, la haa ou asa, la leume ou pure . ." The actual pronunciation would be represented thus: "Otom ö'fa e selo, la ha' ou asu, la leum ou pure ..."

As a matter of fact neither of the existing orthographies satisfies anyone: Father Lejeune is reforming the Roman Catholic one, and the Methodist system puzzles every white man.

It may seem sheer presumption to attempt after a stay of not quite four months to unravel a problem which has baffled residents of old standing. But as a matter of fact the language is very easy, if only the investigator is firmly convinced that if words have different forms, the use of each form must be governed by definite rules. But residents in Rotuma hearing sometimes pure and sometimes puer have been inclined to set it all down to the native's "little ways of speaking" and have therefore not been induced to seek for rules where they assumed there were none.

1 I must acknowledge my indebtedness to Rev. C. Roget, of the Methodist Mission, and Rev. Father Lejeune, of the Marist Mission, who have supplied me with literature which has been of great help to me. In fact, imperfect as the orthographies may be, I could not have made head or tail of the language without their aid.

2 Proc. of the Queensland Branch of the Geog. Soc. of Australasia, 1st session, 1885-6. 
For my first clues I am much obliged to Rev. C. Roget, who assisted me in the cross-examination of one of his native ministers. The clues thus obtained I kept in mind while being spoken to, or while taking down tales and legends which I recorded as they sounded. Some of them were confirmed by experience and some rejected or modified. The outcome is the present outline.

\section{Consonants.}

The following are the consonants used in Rotuman :-

f, h, k, l, m, n, ng, p, r, s, t, tsh, v.

$h$ at the end of a syllable tends towards German $c h$.

$k$ would be represented more accurately by $\chi$.

$n g$ as in sing.

$s$ inclines to $s h(\check{\mathrm{s}})$.

$t s h$ is spelt $t s$ in the Roman Catholic books. It is indifferent which spelling we adopt as it really lies between the two, but most Englishmen would identify it with English $c h$.

$v$ is so spelt by both missions, but as a matter of fact it is neither $v$ nor $w$ before a vowel, and it is distinctly more like $w$ at the end of a word, so much so that I always spelt Sau kamo at first for Sav kamo. Still not to depart too widely from the accepted spelling I will keep to the $v$.

is like the Samoan break : it represents likewise an original $k$. It is not noticed at all by the present orthographies, yet, as we shall see, certain sound changes must always remain a puzzle until we recognize its existence. It is not to be mistaken inside or at the end of a word, but at the beginning I am rarely certain.

\section{VOWELS.}

The fundamental vowels are-

$a, e, i, o, u$.

$e$ and $o$ are moderately broad.

These five vowels are the only ones used in the Methodist spelling. The native knows, or rather feels, the conditions under which these vowels are modified, and therefore modifies the vowels accordingly, as he reads; but a European, ignorant of the rules, finds no guidance in the writing, as these vowels are apt to be considerably modified by a succeeding $e$ or $i$, or $u$, giving rise to the following derivative vowels.

(1) $a$, followed directly or indirectly by $e$, becomes $\ddot{a}$ which sounds like a very broad $e$. This happens, however, only under certain conditions, which are that $a$ be long or both accented and long. My uncertainty on this point is due to the fact 
that I attended to the accent only while I was in Rotuma, and this seemed to account for almost all cases.
$V$ ä́e: to divide.
M. Vae.
S. Vae. ${ }^{1}$
Vä̀ve : fast.
M. Vave.
S. Vave.

But :

Vaséa, Varéa : proper names.

aléte: snake.

alél: tongue.

There remained, however, one or two exceptions :

tá'e : don't.

káte $^{2}:$ not.

It was not till after I had left Rotuma that quantity occurred to me as being the sole or joint factor. But as this only occurred to me because in my memory the $a$ of $k a t e$ and $t a$ 'e were distinctly short, whereas $\ddot{a}$ was always long, it may safely be assumed quantity governs, the only doubt being whether it does so alone or with the accent.

If the $e$ is elided $\ddot{a}$ remains $\ddot{a}$.
af : 1000.
M. ef (sic).
S. Afe.

It will be noticed that the Methodist spelling has gone wrong here. It requires indeed a good ear and long practice to distinguish with certainty between $\ddot{a}$ and $e$.

$a$ preceding $\ddot{a}$ is attracted to it :

väväne: husband. M. vavane.

(2) $a$ before $i$ becomes $a$ subject to the same conditions and doubt as the change of $a$ to $\ddot{a}$; $a$ is a very broad $o$ and is spelt $o$ by the Roman Catholics, but this makes it impossible to distinguish many words, whereas there is no confusion with the Methodist spelling. This will be clearer as we proceed.
áitu (? aítu): spirit.
M. oiitu (sic).
S. aítu.
mátit : cold (objective).
M. matiti.

But :

matit : cold (subjective).

hanisi: to love.

$a$ in both these words is distinctly short (in my memory).

This law is still in operation and affects words borrowed from the English :

Tomási: Thomas; but-

Akanisi: Agnes.

$a$ before $a$ is not attracted :

lalavi: feather.

${ }^{1}$ M. = Methodist spelling. S. =Samoan. F.=Fijian. U.=Uvean (Wallis Isl.).

2 The full form only occurs in poetry; in prose it is always kat. 
It may be in this case because the first $a$ is short (as far as memory may be trusted).

(3) $a$ before $u$ becomes $a$ under the same conditions and with the same reservations as for $\ddot{a}$ and $a$ before $i$ :

Sau : sacred chief. M. Sau. F. Sau.

hafu: stone. M. Hafu. F. vatu.

But :

hanúa: land. S. fanua. F. vanua.

atúa: ghost. S. atua.

In the following word I am sure the $a$ is short :

af: away (spelt by the natives $a f u$ ). $\quad$ S. atu.

On the other hand we have-

$$
\text { af }(a f u): \text { a row. F. } a t u \text {, }
$$

about which I would not express an opinion.

(4) $e$ is narrowed by following $i$ or $u$ :
lele $i$ : good.
S. and U. lelei.
pệü: war.

Exception : lépi : sandy point, not lépi. Query : lépi?

(5) $o$ is also narrowed by following $i$ and $u$; with the same remarks as in the foregoing cases :

$$
\begin{aligned}
& \text { họi : turtle. } \\
& \text { họ’ } i: \text { to return. } \\
& \text { mọu: firm. } \\
& \text { fọl }(u): \text { three. } \quad \text { S. tolulu. }
\end{aligned}
$$

But :

olọlam : lucky.

As this narrowing of $e$ and $o$ does not modify profoundly the sound of the vowel to our ears, it attracts little attention, and I have therefore less carefully noted it. It will not, as a rule, be indicated.

Turtle in Rotuman is hoi, sting-ray is hai. The Roman Catholics spell both hoi. This is obviously a great drawback, for even the context, in such a case, will not tell us how it ought to be pronounced, and which of the two it is. The Methodist spelling hoi and hai is still further removed from the actual sound, but it allows no confusion, and anyone acquainted with the rules will know immediately how the latter word is to be pronounced.

\section{REDUCTION OF Vowels.}

Rotuman, under conditions to be explained later, elides the final vowel. The elision of $e, i$ and $u$ affects certain vowels. This process $\mathrm{I}$ call reduction, and indicate 
by ". over the vowel (German Umlaut). Neither the elision nor the reduction is recognized in the Methodist spelling.

(1) The elision of final $i$ reduces preceding $a$ to $\ddot{a}$ (I apologize for this cumbrous notation, but can devise no better one). This is a sound between a (as $e$ in French $j e$ ) and $\dot{e}$. It is spelt $\grave{e}$ by the Roman Catholics. It is short.

Favi: to anchor-fä̀v.

mafi: tide-möf. F. mati.

In the Methodist spelling these words always remain favi and mafi.

The elision of $u$ does not reduce $a$ :

hafu: stone-haf.

(2) The elision of final $e$ or $i$ reduces preceding $o$ to $\ddot{o}$, which is like German $\ddot{o}$, only tending to $\ddot{u}$, so much so that I have sometimes taken it for $\ddot{u}$ :

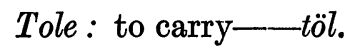

tshōni: to run—-tshön.

Preceding $o$ is attracted to the following $\ddot{o}$ :

poto' $i$ : buttocks-pötö.

ohōni : mother- Öhön.

(3) The elision of final $i$ reduces $u$ to $\ddot{u}$, which sounds like German $\ddot{u}$, only more closed and tending to $i$ :

$$
\begin{aligned}
& \text { muri : behind-mür. } \quad \text { S. Muli. } \\
& \text { 'uli: skin—'ül. } \quad \text { F. kuli. }
\end{aligned}
$$

$a$ preceding $\ddot{u}$ is changed into $\ddot{a}$ :
máuri : to live-mä̈ür.
U. $M a^{6} u r i$.

Here it is that we see the importance of '. For the second vowel of a diphthong is never elided, any two successive vowels at the end of a word being reckoned as a diphthong. Thus

hoi can never become hö, but

$h o^{\prime} i$ regularly becomes $h \ddot{o}$.

Until the European recognizes the existence of ', he cannot make out why M. fai (to write) is sometimes pronounced fä, whereas M. fai (to fell) always remains fai. The explanation is that the first is

$f a^{\prime} i$, which by reduction becomes $f \ddot{a}$, while the second is

fai, which, admitting of no elision, remains fai.

In the same way

$h o^{\prime} i$ (to return) makes hö', but hoi (turtle) makes hoi.

$h a^{\prime} i$ (to blow a gale) makes hä' ; but hai (sting-ray) makes hai.

The full list of Rotuman vowels is therefore :

$a, \ddot{a}, a, \ddot{a}, e, e, i, o, o, \ddot{o}, u, \ddot{u}$. 


\section{Absolute and Construct Cases.}

All uncompounded words in Rotuman except some monosyllables ${ }^{1}$ and those ending in diphthongs have two forms.

The full form always ends in a vowel and never has two consonants together (provided it is not a compound). In this form Rotuman words are like those of any Polynesian language.

The short form elides the last vowel with reduction of the penultimate, if reducible, or it transposes the last consonant and vowel :

$$
\begin{aligned}
& \text { La'o: to go_la'. } \quad \text { F. Lako. } \\
& \text { mōri: orange_mör. } \quad \text { S. moli. } \\
& \text { fäenga: speech_fäeang. }
\end{aligned}
$$

In actual speech most words end in a consonant, and compound words generally have two successive consonants at the point of suture, which gives the language a very un-Polynesian sound :

fuang $r i$ : foundation, from funga (standing place) and $r i$ (house).

$\ddot{o}^{\prime} f a$ : father, from $o^{\prime} i$ (parent) and $f a$ (male). M. oifa.

The full form I will call the " absolute case," and the short form the "construct case." These terms, borrowed from Hebrew grammar, do not fit exactly, but they express sufficiently the nature of both, and will do till something better is suggested.

Here is a representative list of words in both cases :

Absolute.

Mafa : eye,

la'o: to go,

Vävǟne: husband,

$f a^{\prime} i:$ to write,

anasi : mullet,

hafu: stone,

feke: to be angry,

he'o: to call,

pelu: war,

fepi: to be late,

$l i$ ' $u$ : deep sea,

osi : to prepare,

to' $i$ : to break,

tole: to carry,

mo'o: to hide,

futi: to pull,
Construct.

maf.

$l a^{\prime}$.

vävän.

$f \ddot{a}$.

anäs.

haf.

fek.

$h e$ '.

pel.

fep,

$l i$.

ös.

tö'.

töl.

mo'.

füt.

1 Others are reduced to a consonant, thus $r a$ generally occurs as $r$. 
Words ending in a consonant and $a$, when the antepenultimate is other than $a$, are peculiar. They invert the final syllable, placing the $a$ before the consonant :

$$
\begin{aligned}
& \text { Rotuma-Rotuam, } \\
& \text { funa: eel-fuan, } \\
& \text { ho' } a \text { : to take-hoa'. }
\end{aligned}
$$

If the penultimate is $u$, the $a$ becomes $a$ or something near it :hula: month—hual.

If it is $i$, the $a$ becomes $\ddot{a}$ :

mapinga: grandchild-mapiäng,

$h i^{\prime} a$ : to lay hands on - hiä'.

But if $i$ and $u$ are part of a diphthong they do not seem to have that effect:

Founga: proper name-Fouang,

haina: women-haian.

Or the rule may be that this effect does not take place when the consonant is a nasal, as Rotuma and funa make respectively Rotuam and fuan, not Rotuam or fuan.

For the sake of simplicity and because I am not quite clear about these changes, I have not indicated them as a rule, but spell hual, hi' $a$.

In some words $e$ and $o$ suffer this inversion : it is not quite clear which do and which do not: all I can say is that it only occurs where there could be no reduction of the antepenultimate. Thus :

$$
\begin{aligned}
& \text { pure: to rule-puer, } \\
& \text { mairo: a plant_maior, } \\
& \text { piko: lazy-piok, } \\
& \text { siko: to lie-siok; }
\end{aligned}
$$

but never

tole-toel, for it is reduced to töl.

Words borrowed from the English are subject to this rule as to all others :

Tevita : David_-Teviat (not Teviät),

suka: sugar--suak.

Mr. Roget tells me he has heard utsha for a watch, the process being reversed: the form uatsh is conceived as the construct case whence the absolute utsha is deduced.

The inverted form, though equally long in writing, is pronounced more rapidly than the full form, and is felt as shorter. The vowels, as we have seen, have a tendency to be reduced. One informant condemned hosa ne'ai (flower) as slow (fep); it should be hoas ne 'ai. "Some things," he added, "you must speak quickly, and some things you must speak slowly." It is because they have not realized this that Europeans have made so little progress with the language.

The Methodist spelling does not as a rule indicate the inversion. 


\section{Elided Absolute Case.}

The last vowel is sometimes elided in the absolute without any modification of the preceding vowel:

han for hani: woman,

rosrosi : crafty (not rösrosi).

THE $E$-FORM.

Many words ending in $a$ often change this $a$ into $e$ :

Rotuma—Rotume.

atua-atue.

Words with the suffix nga never change $a$ into $e$. I have never heard fäenge.

Words such as moa (fowl) and roa (long) also have no $e$-form. The rule is possibly that words ending in diphthongs have not the $e$-form.

\section{Use of the Absolu'te CASE.}

The absolute case is used:

(1) Always in poetry, except sometimes as the end of a line, thus :

Langi ta ha' iha'i ma faï̈k,

vili sio ke Ferekituanäk.

Sa aitu ta väenga rue, etc. ${ }^{1}$

In prose this would be: Läng ta hä'hä' ma faiäk, vil sio ke Ferekituanaki. Sa aitta väeang rua (? rue). ... .

(2) In nouns and attributive adjectives not followed by any determinant, nor preceded by the indefinite article $t a$, nor forming a compound verbal expression. The rule can only be stated negatively, and can only be understood by referring to the cases in which the construct case is used.

TSHULI fer : the tshuli birds fly, FAMORI $f e a$ : the people are afraid, as TONGI : a hereditary name, $f a$ MAFPONGI : a blind man, hä口n PIKo : a lazy woman.

(3) Nouns with the article $-t$ :

PUREt e Ahau : the Commissioner in Ahau, HANIt onon fesi: the woman to whom the fesi tree belonged.

1 “ The wind blew, blew and was weary; only Ferekituanaki fell. The sa aitu were divided into two teams. . . . ." (The Legend of Tokainiua.) 
(4) Names of places in which the speaker is not:

ngou la' se ROTUMA : I go to Rotuma.

Also names of places or persons when no compliment is intended:

Tausie: proper name of a commoner (from Tausia),

Motusa : if a Motusa man is speaking to an outsider.

(5) Nouns in the vocative when followed by e :

Tshiotshi $\bar{e}$ ! Heigh! George!

(6) Verbs in the future under conditions I cannot define, but it would seem that when the future indicates purpose the absolute is used :

nam la $n g^{1} \mathrm{KA}_{0}^{\prime} \mathbf{I}$ : give it that I break it,

ngou kat inea $r$ la FÄEANG AKI se ngangatsh te' is: I don't know

it (well enough) to relate to this gentleman.

(7) Verbs with the suffixes $m(\underline{e})$ (hither), a, en $(\underline{a})$, of, af(u), ang:

suRum : to come in,

mata hän ta MENGUa: and the woman was comforted,

ofren : it is all over,

suRuof : to go in,

HAIINOSOang: to marry each other.

(8) Questions seem to affect the absolute :

ingka' $i$ ? No?

In the simple affirmative it is ingkä'.

(9) The elided form of the absolute seems only to be used at the end of a sentence, or as the first part of a compound word in the absolute case :

fa Rosrosi : a crafty man.

Use of the Construct Case.

(1) Nouns and attributive adjectives followed by the article $t a$, by an attributive adjective or an adverb :

FAMÖR Rotuma : Rotumans,

$f a$ MAFPÖNG $t a$ : the blind man,

HÄN PIOK pau : a very.lazy woman.

(2) Nouns preceded by the indefinite article $t a$ :

ta hän : a woman.

(3) Nouns in the vocative :

püs! Pussy!

Teviat! David!

Tua'! Tu'a!

Short for ngou (I), or more probably a (hypothetical) ngo. Cp. Otou and oto : mine. 
(4) Names of a place in which a man is at the time:

ia pum se UAF : he came to land (if the speaker is on shore).

Also in a polite way :

Tausia : name of a chief,

Motuas : if an outsider is speaking to a Motusa man.

(5) After non-locative prepositions the construct case seems usual though not invariable :

po $e$ MISIAL : to catch the measles. (Lit., to be caught in the measles.)

This may possibly be explained as a compound verbal expression: to catch-measles ( $v$. infra).

(6) Verbs and predicates except sometimes in the future :

ia MAFPÖNG : he is blind,

TÖNG as : to inherit a name,

äe PIOK : you are lazy,

ia PUER se Rotuam: he rules Rotuma.

(7) Nouns used indefinitely as the object of a verb and immediately following it, and translated in English by a plural noun without the article :

ngou 'a Mör : I eat oranges,

$f \ddot{a}{ }^{\prime}$ säss : to draw sea water,

Rotuam 'a FAMÖR : Rotuma ate men (was cannibal).

This rule seems to be $a$, corollary of the preceding one, for the noun with the verb forms a compound verbal expression : ' $a$ mör is orange-eating: 'a famör is cannibal. This explanation is borne out by the fact that when such an expression is used as an attributive adjective it stands in the absolute :

fa 'a famōri: a cannibal. (Lit., a man eating men.)

$M a$ the possessive, meaning "to possess," "to have," is treated like a verb :

Sau ma on siav: the Sau has a fan (Abs. siva). (Lit., the S. with his fan.)

Ngou ma oto puk: I have a book (Abs. puku). (Lit., I with my book.)

\section{USE OF THE $E$-FORM.}

The $E$-form is used :

(1) With the article $-t$ :

atuet : ghost,

rän ruet: the second day (rän rua = two days). 
(2) In answer to the question what is it, or in apposition:

Rasmutmut, atue : Rasmutmut, a spirit,

tupue: it is a tupua.

(3) I have only noticed the form Rotume as an adjective as in :

fa Rotume: a Rotuma man.

Cases 2 and 3, and also rän ruet, may be grouped together as adjectival, but that does not explain (for the present at least) the $e$-form of names of persons such as Founge, Tausie.

In the above examples the $e$-form is the absolute case. It is plainly opposed to the construct in Tausie, which is the ordinary form, whereas Tausia is the respectful form. But

(4) they always say: .

hanue ta, tupue ta

where the construct case is required. On the other hand we have ta hanua, not ta hanue.

The $e$-form may therefore be said to be always absolute with one exception which we cannot at present explain.

\section{The Two OrthographiEs.}

We can now see how it is that two so opposed systems of orthography can have arisen in Rotuma.

The Methodist orthography writes everything in the absolute case and takes no account of the modification of vowels. To a native this presents no great difficulty, as he can always infer the proper form of the word from the neighbouring sounds and from the syntax. Confronted with the following text:

Ia faefaenga ma Sungukuru e Tarasua, ma ia kota imo kava, ma lao se Ainafa. (He talked with S. in T. and then he drank kava, and went to Ainafa), he transforms it, as he reads, into : Ia fäefäeang ma Sungkur e Tarsua, ma ia kota iom kav, ma la' se Ainafa.

The Methodist spelling is really the native spelling and has been to a certain extent dictated by them. It is the best in existence, since we can always infer the construct from the absolute. But it stands to reason that great proficiency in reading is hardly attainable when almost every word has to be recast as the reader proceeds. I have indeed been struck by the slowness with which even some of the native ministers read. Moreover, some cases remain ambiguous. Thus famori ala may stand for famör ala (dead men), or famori al (the men died). If I write po anasi it is not clear whether I mean catching mullets ( $p o$ anäs) or catching the mullets (po anasi).

I believe the use of the Umlaut would present no difficulties to the natives, at least the younger generation. If they have imposed the present system it is 
because they are unacquainted with any mode for representing the derivative sounds. They cannot therefore omit the final vowel in writing, or it would not be clear what the word is. Thus we have 'uli (skin) and 'ulu (bread-fruit): if we drop the final vowel in writing without modifying the first syllable, it is not clear whether ' $u l$ stands for 'uli or 'ulu. If we use the Umlaut there can be no doubt whatever.

The Roman Catholic orthography on the other hand spells most words in the construct. This is the natural tendency of the White Man; for as most words in any sentence are in the construct, it is the form he learns first; when the absolute does occur he does not take much notice of it. This orthography has not the virtue of consistency, and, as we have seen, the sounds are badly represented, leading to confusion. The relationship of fundamental to derivative vowels is also obscured.

\section{The Order of the Sentence, etc.}

The rules set forth above are the essence of Rotuman grammar. If this initial difficulty is passed the rest is plain sailing, and formidable as it appears at first, Rotuman turns out to be much easier than languages like Fijian, Samoan, or Tongan. The order of the sentence is the European : subject, verb, object; only that the adjective follows the noun, as in the neighbouring languages.

There is no distinction between past and present; the future is indicated by la: ngou la la': I shall go.

fu se' la mak: stand up to dance.

\section{The Article.}

The article is perhaps the only remaining difficulty. There are three articles : $t a$ (the) after the noun, $-t$ after the noun, $t a$ (a) before the noun.

The article is never used in the plural :

fa fol : the three men.

The use of $-t$ requires some explanation. It is used :

(1) When a thing is defined by its place:

Solot e Sisilo: the hill in Sisilo, pelut e Lopta: the battle of Lopta.

(2) When it is defined by a relative sentence :

fat ne lim e asa: the man who came yesterday,

fat onon hanuet e Paptea: the man to whom belonged the land in P.

(3) In the (distributive) idiom:

le'et ma on fupang, le'et ma on fupang: a man with his flesh, a man with his flesh, i.e., each man with his flesh.

(4) With possessives:

Oto hanuet : my land.

The distinction between oto hanue and oto hanuet is not clear. Oto hanueta would appear to mean " that land of mine." 
(5) Answering to our "there was ..."

Hanit, on as .... there was a woman whose name was . . .

$H \ddot{a} n$ ta on as would mean : that woman was called.

\section{SPECIMEN.}

I will conclude with a specimen of the language, which the reader can easily translate with the following vocabulary of words that have not already occurred:

Sau noh e on hanue ta, ma lim la kakau e vaitokat e hün haf. Ma ia mamas se ulang hafta; ma haf ta es lelea e fa ta. Noh e Orọi ta inos ta, eake noh e Rän te. Ma, hän ta efmafua e Saut. Ma nono, ma hă on hula, mata a'su sio, on le'ta, ma le' fa, ma he' se' on as Vavaiparó. Mata nonồ, ma kauike tak se fän hăf ma mös; mata hän ta hia' ma po se anasi, ma hanghang on le'et. Ma ia hanghang on le'ta e anasi ma mafua.

Noho: to dwell-e: in-ona: his-ma, mata: and-lim, leume: to come -kakau: to bathe-vaitoka: fresh water spring coming out on the beach-huni: base-mamas: to dry-se: to-ulanga: top-es lelea: to bear children-le'e: person, child-Oroi : Spirit Land-inoso: man and wife, to marry-eake: notRän te: the World (opposed to Spirit Land)-ef mafua: to conceive-nono: in course of time- $h a^{6} u$ : to reach, arrive-hula: month-a'su: to give birth-sio: down-he'o: to call-se (? se'): a particle after verbs that seems to mean completion-asa: name-kauike: shoal-taka: to lie-fani: underneath-mose: to sleep-po: to catch—anasi : mullet—hanga: to feed—mafua: old, adult.

\section{Comparative Phonetics.}

The Rotuman consonants have suffered considerable changes, as will be seen on comparing them with the Fijian and Samoan :

\begin{tabular}{|c|c|c|c|c|}
\hline Fijian. & \multicolumn{2}{|c|}{ Samoan. } & \multicolumn{2}{|c|}{ Rotuman. } \\
\hline $\mathrm{mb}: m b a$ & $=$ & - & $=$ & $\mathrm{p}: p a$ \\
\hline $\mathrm{dh}(\delta):$ modhe & $=$ & $-: m o e$ & $=$ & $\mathrm{s}$ : mose. \\
\hline nd: ndalinga & $=$ & $\mathrm{t}:$ talinga & $=$ & $f:$ falinga \\
\hline ngg: wungga & $=$ & $: v a^{\prime} a$ & $=$ & $\mathrm{k}: v a k a$ \\
\hline $\mathrm{k}: i k a$ & $=$ & 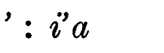 & $=$ & ': $i^{\prime} a$. \\
\hline $\int l a k o$ & $=$ & - & $=$ & 1: la'o. \\
\hline$:\{$ tolo & $=$ & - & $=$ & $\mathrm{r}$ : foro. \\
\hline & & $\mathrm{p}:$ poto & $=$ & $\mathrm{p}:$ poto. \\
\hline$t:$ tolu & $=$ & $\mathrm{t}:$ tolu & $=$ & f : fọlu. \\
\hline : vanua & $=$ & $f$ : fanua & $=$ & $\mathrm{h}:$ hanua \\
\hline
\end{tabular}

